УДК 340.13

DOI https://doi.org/10.32849/2663-5313/2021.2.34

\title{
Тетяна Фулей,
}

канд. юрид. наук,

начальник відділу наукових досліджень проблем судочинства

та науково-методичного забезпечення суддівської освіти

Начіональної школи суддів України

ORCID ID: 0000-0002-9800-8785

\section{ЗАСТОСУВАННЯ СУДАМИ ЗАСТАРІЛИХ ЗАКОНОДАВЧИХ НОРМ ЯК ПЕРЕШКОДА ДЛЯ ЗАБЕЗПЕЧЕННЯ ДОСТУПУ ДО ПРАВОСУДДЯ}

Стаття присвячена проблематиці застосування судами застарілих законодавчих положень, що є перешкодою для забезпечення доступу до правосуддя. На прикладі рішення Європейського суду з прав людини у справі «Левчук проти України», у якому констатовано порушення статті 8 Конвениії про захист прав людини і основоположних свобод через недотримання державою позитивних зобов'язань щодо ефективного захисту заявниці від домашнього насильства, з огляду на відмову національних судів у позові про виселення ї̈ колишнього чоловіка, продемонстровано вади тлумачення q застосування статті 116 Житлового кодексу Української РСР у сучасних умовах. На підставі аналізу рішень начіональних судів у справі І. Левчук зроблено висновок, що не можна вважати належним застосуванням закону в спосіб «недобачання» певного слова в його тексті. Наголошено, що «правила сочіалістичного співжиття» в статті 116 ЖК є стійкою юридичною конструкиією часів побудови соціалізму, яка внаслідок вилучення слова «сочіалістичний» утрачає свою суть, $і$ звернуто увагу, що начіональні суди, застосовуючи саму норму, оминають ие слово в тексті статті. Окреслено проблему: чи можна вважати застарілі положення житлового законодавства «законом, який підлягає застосуванню». Продемонстровано проблеми застосування статті 109 ЖК, яка унеможливлює виселення особи без надання іншого постійного жилого приміщення. Наголошено на необхідності тлумачити статтю 109 ЖК у системному зв'язку з преамбулою ЖК, де декларується розв'язання житлової проблеми в радянські часи. На підставі судової практики показано негативні наслідки застосування статті 109 ЖК в сучасних умовах для власника житла. Наголошено на помилковості сприйняття й застосування практики ССПЛ як такої, яка в приниипі нібито не допускає виселення. Ураховуючи, що однією з вимог верховенства права, які стосуються доступу до правосуддя, виокремлених на підставі аналізу Доповіді Венеиійської комісії «Верховенство права», $є$ наявність у суду повноважень здійснювати юридичну кваліфікаиію, вирішувати питання факту й застосовувати належний $і$ чинний закон до фактичних обставин згідно з достатньо прозорою та передбачуваною (несвавільною) методологією тлумачення, зроблено висновок, що застосування судом неналежного або нечинного закону, так само як і неналежне застосування закону, є порушенням вимог верховенства права й перешкоджає забезпеченню доступу до правосуддя.

Ключові слова: доступ до правосуддя, домашнє насильство, практика ЄСПЛ, «закон, який підлягає застосуванню», виселення.

Постановка проблеми. Доступ до правосуддя є одним із порівняно нових концептів для вітчизняної юридичної науки; відповідний термін увійшов у науковий обіг лише наприкінці ХХ століття. Ухвалення Венеційською комісією Доповіді «Верховенство права» [1] у 2011 році сприяло не лише усталеності цього терміна в українській правничій мові, а й сприйняттю «доступу до правосуддя» як одного з необхідних елементів, характерних як для «верховенства права», так i «правової держави», щодо яких на європейському континенті досягнуто консенсусу. У національному законодавстві доступ до правосуддя вперше закріплено як одну із загальних засад кримінального провадження (пункт 14 частини першої статті 7 та стаття 21 Кримінального процесуального кодексу України (далі - КПК України) 2012 року [2], а в частині третій статті 7 Закону України «Про судоустрій та статус суддів» від 2 червня 2016 року № 1402-VIII зазначено, що доступність правосуддя для кожної особи забезпечується відповідно до Конституції України та в порядку, установленому законами України [3].

Проблеми, пов'язані із забезпеченням доступу до правосуддя, особливо актуальні 
для вразливих груп та осіб. Варто згадати, що розвиток концепції «доступ до правосуддя» (англ. access to justice), основні положення якої розроблені в 1960-70-х роках представниками т.зв. «флорентійського проекту доступу до правосуддя» (Florence Access to Justice Project), розпочався шляхом аналізу бар'єрів, із якими стикаються насамперед соціально вразливі та незаможні особи. Загальновизнано, що потерпілі від гендерно зумовленого й домашнього насильства належать до таких вразливих категорій. Так, запобігання насильству й боротьба 3 насильством щодо жінок і домашнім насильством і забезпечення рівного доступу жінок до правосуддя є стратегічними цілями Ради Європи, визначеними Стратегією гендерної рівності Ради Європи [4, с. 17, 22-28]. Важливо зазначити, що засоби судового захисту мають ураховувати індивідуальні особливості конкретних порушень прав людини, усувати правопорушення, а також забезпечувати відшкодування завданої шкоди [5, с. 24], а рішення Європейського суду з прав людини (далі - ЄСПЛ або Суд) засвідчують наявність перешкод для доступу жінок до правосуддя й дали змогу Суду сформулювати власні стандарти, зокрема, у справах насильства щодо жінок, серед яких - розвиток доктрини позитивних зобов'язань [5, с. 9].

Одним із рішень ЄСПЛ, яке викликало значний суспільний резонанс як в Україні, так і за іï межами, є нещодавнє рішення у справі «Левчукпроти Украйни», у якому констатовано порушення Україною статті 8 Конвенції про захист прав людини та основоположних свобод (далі - Конвенція), зокрема через те що «реакція цивільних судів на позов заявниці про виселення іiі колишнього чоловіка не відповідала позитивному обов'язку держави забезпечити заявниці ефективний захист від домашнього насильства» $[6$, п. 90]. Звертає на себе увагу й доволі швидкий розгляд справи Судом 3 огляду на її пріоритетність, оскільки заявниця та її діти продовжували проживати в одній квартирі з її колишнім чоловіком і піддавалися фізичному та психологічному насильству. Це рішення ЄСПЛ учергове привернуло увагу до проблематики боротьби з домашнім насильством та актуалізувало дискусію щодо необхідності ратифікації Україною Стамбульської конвенції (Конвенції Ради Свропи про запобігання насильству стосовно жінок і домашньому насильству та боротьбу з цими явищами, CETS № 210) [7]. Проте, на відміну від більшості справ, пов'язаних із домашнім насильством, справа «Левчук проти Украӥни» стосується не розслідування випадків неналежного поводження, а виселення.
Загалом категорія спорів про виселення $\epsilon$ непростою, їх вирішення національними судами ускладняються неправильним розумінням і застосуванням низки рішень ССПЛ щодо України, як-от: «Кривіцька та Кривіиький проти України» [8], «Дакус проти України» [9] та «Садов'як проти Украӥни» [10] У цих справах ССПЛ визнавав порушення статті 8 Конвенції не в останню чергу через неналежний розгляд національними судами певних аргументів заявників і відсутність необхідного обгрунтування в судових рішеннях. Водночас, на відміну від вищенаведених, справа «Левчук проти України» висвітлила проблеми, пов'язані не лише з неналежним мотивуванням судових рішень, а й застосуванням судами застарілих законодавчих положень, у цьому випадку Житлового кодексу Української РСР [11] (далі - ЖК), у сучасних умовах, що є суттєвою перешкодою доступу до правосуддя. На нашу думку, вирішення проблеми, чи є застарілі положення житлового законодавства «законом, який підлягає застосуванню» (у термінології, наприклад, частини другої статті 376 і частини третьої статті 412 Цивільного процесуального кодексу України [12] (далі - ЦПК)) та чи можуть вони бути застосовані у спосіб, як це зроблено національними судами у справі I. Левчук, що призвело до порушення державою конвенційних зобов'язань щодо захисту прав людини, має значне практичне значення, а тому потребує наукового дослідження.

Серед вітчизняних науковців проблеми доступності правосуддя в цивільних справах досліджували Н. Сакара, О. Соломахіна, в адміністративному судочинстві Ю. Битяк, А. Руденко, Л. Савранчук, М. Смокович, загальнотеоретичну характеристику права на доступ до правосуддя та його юридичного забезпечення здійснила в дисертаційному дослідженні I. Верба, гарантії реалізації доступності правосуддя - О. Овчаренко, конституційну природу та конституційно-правовий механізм гарантій права на доступ до правосуддя, окремі проблеми його законодавчого регулювання досліджував А. Лужанський; доступу до правосуддя присвячена низка зарубіжних публікацій, 3-поміж найновіших виділимо ті, авторами яких є А. Бреннінкмейєр (А. Brenninkmeijer), К. Дарк (K. Dart), M. Мyp (M. Moore), Л. Тухі (L. Toohey), Д. Тухі (D. Toohey), Дж. Чан (G. Chan), Дж. Шарп (G. Sharp). Категорія «якість закону» в автономному тлумаченні ЄСПЛ і питання застосування судами загальної юрисдикції Конвенції в разі «неякісного» законодавства досліджувалися Я. Берназюком, П. Гуйваном, В. Паліюком, однак увага 
акцентувалася переважно на розкритті таких вимог до закону як «доступність», «передбачуваність» i «зрозумілість», а предмет позову не стосувався виселення. Питання «неправильного застосування норм матеріального права» висвітлювалися в роботах М. Бояринцевої, К. Гусарова, І. Смельянової, О. Ломоносової, В. Комарова, В. Плевако, А. Помазанова, О. Тимошенко, М. Ульмера та інших, зокрема в аспекті апеляційного та касаційного перегляду судових рішень або ж проблематики законності й обгрунтованості судового рішення. Водночас досі поза належною увагою дослідників залишаються питання належного теоретичного осмислення таких категорій, як «закон, який підлягає застосуванню» та «закон, який не підлягає застосуванню», як окремих випадків більш загальної категорії «неправильне застосування норм матеріального права», а також проблематика застосування застарілих законодавчих положень крізь призму забезпечення доступу до правосуддя.

Мета статті - окреслити проблему: чи є застарілі положення житлового законодавства «законом, який підлягає застосуванню» та продемонструвати на прикладах справ про виселення наслідки неправильного застосування судами застарілих норм житлового законодавства в сучасних умовах, що є перешкодою реалізації доступу до правосуддя.

Виклад основного матеріалу. Доступ до правосуддя дає можливість особі захистити себе від порушення її прав; це елемент верховенства права, що наскрізно присутній у всіх галузях та інститутах права, пов'язаних із вирішенням спорів [13, с. 16]. Однією з вимог верховенства права, які стосуються доступу до правосуддя, виокремлених на підставі аналізу вищезгаданої Доповіді Венеційської комісії, $є$ наявність у суду повноважень здійснювати юридичну кваліфікацію, вирішувати питання факту й застосовувати належний і чинний закон до фактичних обставин згідно з достатньо прозорою та передбачуваною (несвавільною) методологією тлумачення [14].

Отже, застосування судом неналежного або нечинного закону, так само як і неналежне застосування закону, є порушенням вимог верховенства права й перешкоджає забезпеченню доступу до правосуддя.

Розглянемо, яким чином справа «Левчук проти України» розкриває проблему тлумачення й застосування окремих положень ЖК у сучасних умовах як «закону, який підлягає застосуванню». Окрім установлення фактичних обставин справи та їх оцінки судом, у цій справі особливо важливе значення має встановлення юридичної основи справи, яка передбачає: пошук норми права, що підлягає застосуванню; перевірку правильності тексту того нормативно-правового акта, у якому міститься норма; перевірку чинності норми й параметрів її дії в часі, просторі та за колом осіб; з'ясування змісту норми, у тому числі пошук актів офіційного тлумачення. Усі ці дії об'єднані метою правильної правової кваліфікачї встановлених фактичних обставин, тобто юридичної оцінки всієї сукупності фактичних обставин справи шляхом співставлення цього випадку до певних норм права й установлення норми, яка поширюється на цей конкретний випадок [15, с. 238].

Задовольняючи позов Ірини Левчук про виселення іiі колишнього чоловіка на підставі статті 116 ЖК, Рівненський міський суд у рішенні від 4 квітня 2017 року зазначив, зокрема, що доводи позивачки про систематичне порушення відповідачем правил співжсття (виділено авторкою - T. Ф.) підтверджуються неодноразовими зверненнями позивачки та сусідів на службу 102 відділу поліції, нанесенням тілесних ушкоджень позивачці та притягненням відповідача до відповідальності за вчинення домашнього насильства, передбаченого ч. 2 ст. 173-2 Кодексу України про адміністративні правопорушення (далі - КУПАП), а також показами свідків, які вказали, що застосовані заходи попередження та громадського впливу не дали результатів [16]. Це рішення було скасоване судом апеляційної інстанції, який зазначив, зокрема, що докази, подані сторонами, свідчать про наявність неприязних, конфліктних відносин між членами колишнього подружжя. Хоча колегія суддів уважала за необхідне попередити відповідача про необхідність змінити ставлення правил суспільного співжиття (виділено авторкою - T. Ф.) з колишніми членами своєї сім'ї, вона дійшла висновку, що підстав для застосування до відповідача виселення як крайнього заходу впливу недостатньо [17].

Верховний Суд у складі колегії суддів Другої судової палати Касаційного цивільного суду (далі - ВС) Постановою від 20 серпня 2018 року (справа № 569/7901/16-ц), відмовляючи в задоволенні касаційної скарги I. Левчук, зазначив, що «для застосування норм статті 116 необхідна наявність двох умов: систематичне порушення правил співжиття (виділено авторкою - $T$. Ф.), а також вжиття заходів попередження або громадського впливу, які не дали позитивних результатів» [18]. I хоча далі в Постанові зазначається, що судом установлено, що відповідач зловживає спиртними напоями, постійно влаштовує скандали та конфлікти, 
принижує позивачку, свідками чого стають діти, а пані Левчук неодноразово зверталася з повідомленнями щодо неправомірної поведінки відповідача, однак оскільки за цими заявам заходів попередження або суспільного впливу прийнято не було, то ВС дійшов висновку, що судове рішення апеляційного суду є обгрунтованим і лише факти звернення у відповідні органи зі скаргами на порушення правил суспільного співжиття (виділено авторкою - Т. Ф.) без застосування до винного заходів впливу цими органами не $€$ підставою для виселення [18]. При цьому $\mathrm{BC}$ не згадав про притягнення кривдника до адміністративної відповідальності за вчинення домашнього насильства.

Безперечно, притягнення особи до відповідальності, передбаченої ч. 2 ст. 173-2 КУпАП (зауважимо, що вперше відповідальність за вчинення домашнього насильства була передбачена в КУ ПАП ще у 2003 році, відтоді санкції неодноразово (у 2008, 2010, 2015 та 2017 роках) посилювалися), не наведене серед підстав виселення, викладених у статті 116 ЖК, останні зміни до якої вносилися в 1991 році. Водночас не можна не зауважити, що встановлення судом фактів притягнення особи до відповідальності за рішенням суду є достатнім і належним доказом асоціальної поведінки особи, принаймні не меншим, ніж «заходи запобігання і громадського впливу», а повторність учинення відповідачем домашнього насильства свідчить про безрезультатність таких заходів. Проте не менше, ніж оцінка цих обставин справи, звертає на себе увагу неточність цитування національними судами, у тому числі й $\mathrm{BC}$, тексту статті 116 ЖК: як убачається з рішень, суди наводили формулювання «правила співжиття», «правила суспільного співжиття» та «правила спільного проживання», тоді як у статті 116 ЖК Української РСР вказано: «якщо наймач, члени його сім'ї або інші особи, які проживають разом із ним, систематично руйнують чи псують жиле приміщення, або використовують його не за призначенням, або систематичним порушенням правил сочіалістичного співжиття (виділено авторкою - $T$. Ф.) роблять неможливим для інших проживання з ними в одній квартирі чи в одному будинку, а заходи запобігання та громадського впливу виявилися безрезультатними, виселення винних на вимогу наймодавця або інших заінтересованих осіб провадиться без надання іншого жилого приміщення». Видається, що пошук відповіді на питання, чому в судових рішеннях 2016-18 років випущене слово «соціалістичного» зі статті 116 ЖК, яка є формально чинною, є ключовим для розуміння проблеми здійснення судом правильної та повної юридичної кваліфікації як виконання вимоги верховенства права, що стосується доступу до правосуддя, у розумінні п. 54 Доповіді Венеційської комісії.

Безперечно, мова йде не про факт існування «соціалістичного співжиття» як соціального явища в наш час, а про те, чи не суперечить «непомічання» певного слова в тексті закону загальним правилам юридичного тлумачення, оскільки жодне слово не може тлумачитися як зайве, а значення кожного залежить від тих слів, з якими воно поєднується; слова повинні тлумачитися не окремо, а в сукупному зв'язку, про що писав ще видатний учений минулого $Є$. Васьковський [19, с. 45].

Безумовно, норми ЖК Української РСР 3 «ленінськими ідеями побудови комуністичного суспільства», на втілення яких у життя була спрямована, як зазначено в Преамбулі цього Кодексу, «розроблена Комуністичною партією програма житлового будівництва», не відповідають ні Конституції України, ні сучасним соціальним реаліям, про що, до речі, зазначив Конституційний Суд України в Рішенні від 20 грудня 2019 року № 12-p/2019, де він звернув увагу на те, що ЖК прийнято до набуття чинності Конституцією України, а тому низка його положень є такими, що нівелюють сутність конституційних прав і не відповідають конституційним засадам соціального, економічного розвитку Українського суспільства та держави, тож їх варто привести у відповідність до вимог Основного Закону України [20].

На наше переконання, «правила соціалістичного співжиття» в ЖК є стійкою юридичною конструкцією - термінопоняттям, яке має власний обсяг і зміст і позначає специфічне правове явище, відображає певні елементи правової дійсності. Ознаками юридичних конструкцій $є$ повнота й цілісність, відтак вилучення слова цілковито змінюе їх суть. Цим «правила соціалістичного співжиття» подібна до низки інших, сучасних юридичних конструкцій: наприклад, неможливо вилучити 3 юридичної конструкції «європейська інтеграція» слово «європейська» без вихолощення ㄲï змісту, так само слово «конституційні» 3 «конституційні права і свободи».

Поряд 3 принципами сумлінної праці на благо суспільства, піклування про суспільну власність, вимогами зміцнення колективізму, товариською взаємодопомогою тощо, «правила соціалістичного співжиття» були складником морального кодексу будівника комунізму [21], а їх порушення полягало в таких умисних діях, як учинення скан- 
далів, дебошів, нанесення образ, тілесних ушкоджень, умисному ігноруванні встановлених правил користування жилими й підсобними приміщеннями, невиконанні вимог про дотримання тиші в квартирах і у дворі, а також інших умисних діях, що перешкоджали нормальному проживанню у квартирі чи будинку. Місце вчинення таких дій значення не мало (у квартирі щодо членів сім'ї чи інших осіб, які в ній проживають, у спільній квартирі щодо інших користувачів жилого приміщення чи в окремій квартирі щодо сусідів та інших мешканців будинку) [22, с. 147]. у більш широкому контексті порушеннями правил соціалістичного співжиття вважалося розпивання спиртних напоїв, неробство (варто пригадати, що дармоїдство (рос. тунеядство) у 1961-1991 роках в СРСР було складом злочину, що полягав у тривалому проживанні повнолітньої працездатної особи на нетрудові доходи з ухиленням від суспільно корисної праці, та розцінювалося як «паразитичне існування за рахунок суспільства»), небажання брати участь у різноманітних заходах «на благо соціалістичного суспільства», прояви неповаги до товаришів чи співмешканців тощо. Порушення правил соціалістичного співжиття з погляду соціалістичної моралі й законності, вимагало вжиття «заходів запобігання та громадського впливу», які здебільшого полягали в обговоренні «негідної» поведінки особи на зборах трудового колективу чи зборах мешканців будинку з подальшими наслідками, що доволі яскраво зображено радянським кінематографом.

Ураховуючи наведене, не можна вважати належним застосування статті 116 ЖК у спосіб, як це зробили національні суди у справі Ірини Левчук, а саме шляхом «непомічання» цілісної юридичної конструкції «правила соціалістичного співжиття» в тексті статті, 3 одного боку, і водночас вимагаючи від позивачки доказів ужиття заходів попередження або громадського впливу до відповідача, які не дали позитивних результатів, за наявності фактів притягнення до адміністративної відповідальності її колишнього чоловіка за вчинення домашнього насильства 3 іншого. Як зазначається в рішенні ЄСПЛ, у цій справі, відповідно до пояснень Уряду, стаття 116 ЖК «в принципі була належним законодавчимспособомврегулювання < .. > справи» [6, п. 85, 90] (зауважимо, що в рішенні ЄСПЛ її текст відтворено неповністю й не дослівно [6, п. 49]), однак «у контексті провадження про виселення, порушеного на підставі зазначеного положення законодавства, національні суди, які розглядали твердження заявниці, що в О.Л. періодично ставалися спалахи насильства під час суперечок удома, були зобов'язані оцінити достовірність іï тверджень і ризик учинення насильства в майбутньому, якщо сторони залишаться проживати під одним дахом. 3 наявних у Суду матеріалів не вбачається, що апеляційний суд чи Верховний Суд здійснили комплексну оцінку цих елементів» [6, п. 85].

Стаття 116 ЖК не єдина «соціалістична» норма цього Кодексу. Наприклад, за відсутності самого слова в тексті, глибоко соціалістичною за своєю суттю є стаття 109 ЖК, відповідно до якої громадянам, яких виселяють із жилих приміщень, за загальним правилом, водночас надається інше постійне жиле приміщення, про що зазначається в судовому рішенні. На наше переконання, статтю 109 ЖК також варто тлумачити в системному зв'язку з преамбулою ЖК про те, що «в результаті перемоги Великої Жовтневої соціалістичної революції в нашій країні було створено необхідні передумови для розв'язання однієї з найважливіших соціальних проблем - задоволення потреби трудящих у житлі», оскільки ЖК написано в умовах, коли не було безхатченків як соціального явища. Проте в умовах написання ЖК також не існувало свободи пересування й вибору місця проживання та багатьох інших прав і свобод, зокрема права приватної власності на житло (у сучасному розумінні й масштабах). Логічно, що в умовах суворого режиму прописки в тоталітарній державі в рішенні суду про виселення необхідно було вказати, куди саме особу виселяють, щоб полегшити здійснення за нею нагляду, а жиле приміщення надавалося державою.

Водночас із 1983 року (набрання чинності ЖК) соціальні реалії змінилися настільки, що в сучасних умовах застосування вимог статті 109 ЖК унеможливлюють виселення й тих осіб, які не мають права проживати у відповідному приміщенні. Зокрема, як слушно зазначила колегія суддів Першої судової палати Касаційного цивільного суду в ухвалі від 13 червня 2018 року про передачу на розгляд Великої Палати Верховного Суду справи № 753/12729/15-ц, застосування положень статті 40 Закону України «Про іпотеку» від 5 червня 2003 року № 898-IV [23] та статті 109 ЖК при вирішенні спорів за вимогами нового власника житла про усунення йому перешкод у користуванні власністю шляхом виселення колишнього (колишніх) власника (власників) житла, яке було предметом іпотеки, суперечить основним принципам непорушності й недоторканності права власності. Наявність такого правового механізму, як унеможливлення виселення громадян без надання іншого 
жилого приміщення, яке має бути зазначено в рішенні суду, нівелює сутність конституційних прав і свобод титульного власника майна, оскільки призводить до того, що вони стають декларативними й такими, що позбавлені реального механізму захисту, крім того, покладають на нового власника, який не був пов'язаний із попереднім власником умовами іпотечного договору, індивідуальний надмірний тягар у вигляді обов'язку із забезпечення колишнього власника іпотечного майна постійним жилим приміщення, яке має бути надане одночасно з виселенням [24]. Постановляючи ухвалу про передачу справи на розгляд Великої Палати Верховного Суду, колегія суддів Першої судової палати Касаційного цивільного суду керувалася тим, що $є$ підстави для відступу від висновків щодо застосування норми права в подібних правовідносинах, викладених у раніше ухвалених постановах Верховного Суду України (від 22 червня 2016 року у справі № 6-197цс16 і від 21 грудня 2016 року у справі № 6-1731цс16) [24]. Проте, на переконання Великої Палати Верховного Суду, стаття 109 ЖК, яка закріплює правило про неможливість виселення громадян без надання іншого жилого приміщення, є належним законом, і хоч «не можна не звернути уваги на порушення прав нового власника», проте новий власник може частково поновити свої права шляхом звернення про відшкодування шкоди до продавця, якщо той неналежним чином виконав свої зобов'язання про повне інформування можливих покупців квартири про її обтяження, чи до банку про виконання останнім обов'язку із забезпечення осіб, які підлягають виселенню, іншим житловим приміщенням і відшкодування збитків, а підстав для відступу від висновків щодо застосування норми права в подібних правовідносинах немає [25].

На нашу думку, неможливість виселення колишнього власника 3 посиланням на статтю 109 ЖК є свідченням стійкості соціалістичного праворозуміння та перебування частини суддівського корпусу в радянській світоглядно-правовій парадигмі навіть на 30-му році незалежності України. Судова практика Великої Палати Верховного Суду засвідчує підхід, за якого норми ЖК, які прийняті в час, коли житловий фонд був державним (у віданні місцевих Рад народних депутатів та у віданні міністерств, державних комітетів і відомств, т.зв. відомчий житловий фонд) або громадським (у власності колгоспів, інших кооперативних організацій, їхніх об'єднань, профспілкових та іншим громадських організацій), унаслідок такого помилкового застосування в сучасних умовах покладає на власника приватного житла (незалежно від того, є власник фізичною особою, що придбала житло на прилюдних торгах чи роботодавцем, що надав житло у зв’язку з виникненням трудових відносин тощо) увесь тягар влаштування долі особи, яка протиправно проживає в його жилому приміщенні. Уважаємо, що, замість покладати «надмірний індивідуальний тягар» на власника, одним із варіантів виходу із ситуації є такий: суд може відстрочити виконання рішення про виселення на розумний строк і надати відповідачу час винайняти інше жиле приміщення.

Окрім того, помилковим є сприйняття практики ЄСПЛ як такої, яка в принципі не допускає виселення, оскільки «втрата житла $€$ найбільш крайньою формою втручання у право на повагу до житла» [8, п. 41]. Доречно нагадати, що в жодному 3 трьох рішень ЄСПЛ щодо України - «Кривіщька та Кривічький проти Украӥни» [8], «Дакус проти України» [9] та «Садов'як проти України» [10] - Суд не ставив під сумнів ті обставини, що рішення про виселення було законним і переслідувало принаймні одну з легітимних цілей, визначених пунктом 2 статті 8 Конвенції. Також, на нашу думку, у цих справах виселення відповідачів не суперечило б критерію «необхідності в демократичному суспільстві», якщо б рішення національних судів були належно мотивованими. Наприклад, у справі «Садов'як проти України» ЄСПЛ не лише визнав, що рішення про виселення колишньої дружини військовослужбовця та неповнолітніх дітей з гуртожитку, що належав Львівській академії сухопутних військ, було ухвалено компетентним судом у результаті змагального провадження; цей захід мав підгрунтя в національному законодавстві, а також переслідував законну мету в розумінні пункту 2 статті 8 Конвенції, а саме захист інтересів військовослужбовців, які потребували тимчасового житла у зв'язку із проходженням служби, але й звернув увагу на аргумент Уряду, що будь-яке право на тимчасове проживання у відповідному житловому приміщенні тісно пов'язане зі статусом заявника (у цьому випадку військовослужбовця) та що це право було втрачено у зв'язку з його звільненням із військової служби, зазначивши: «Суд у принципі готовий визнати, що цей аргумент міг бути важливим для вирішення питання щодо пропорційності. Проте його не було включено до обгрунтування національного суду, який ухвалив рішення про виселення» $[10$, п. 33]. Аналогічно в справі «Дакус проти України» ЄСПЛ дійшов висновку, що виселення заявниці та їі малолітнього сина із житла було законним, але непропорційним 
заходом, зазначивши, зокрема, таке: «Суд бере до уваги твердження Уряду про те, що фактологічні доводи заявниці були неправдивими та відповідно до них на момент подій вона фактично проживала в іншій квартирі. У той же час Суд зауважує, що ці питання не розглядалися в рішеннях національних судів. Відповідні аргументи або не були наведені позивачем під час провадження на національному рівні, або були проігноровані судами при обгрунтуванні своїх рішень. $<\ldots>\gg[9$, п. 51$]$.

Неспроможність українського парламенту протягом десятиліть урегулювати суспільно важливі відносини, що стосуються фундаментальних права людини, також уже визнавалася ЄСПЛ, як це було, наприклад, у рішенні у справі «Вєренцов проти України» стосовно свободи мирних зібрань [26, п. 55]. Однак сподівання на прийняття нового ЖК виглядають примарними, оскільки забороняється відмова в розгляді справи з мотивів відсутності, неповноти, нечіткості, суперечливості законодавства, що регулює спірні відносини (частина десята статті 10 ЦПК України) [12], суди й надалі стикатимуться з проблемою застосування застарілих законодавчих положень ЖК.

Водночас стаття 109 ЖК не визначає, ким саме має надаватися жиле приміщення при виселенні особи, ніщо в статті 47 Конституції України не свідчить про те, що це має здійснювати позивач (наприклад, новий власник, орган місцевого самоврядування, якщо житло належить до комунального житлового фонду, підприємство, установа, організація чи держава). Держава, відповідно до частини першої статті 47 Конституції України, лише «створює умови, за яких кожний громадянин матиме змогу побудувати житло, придбати його у власність або взяти в оренду», а відповідно до частини другої статті 47 Конституції України, надання житла державою та органами місцевого самоврядування безоплатно або за доступну плату відповідно до закону передбачено лише для громадян, які потребують соціального захисту. Водночас, як зауважив Конституційний Суд України в Рішенні від 7 листопада 2018 року № 9-р/2018, зі змісту статті 46 Основного Закону України випливає, що держава зобов'язана здійснювати соціальний захист насамперед тих осіб, які не можуть самостійно себе забезпечити шляхом реалізації права на працю та/або позбавлені засобів існування. При цьому соціальна орієнтованість держави та принцип соціальної солідарності не можуть замінити особисту відповідальність людини за власну долю й добробут своєї сім'ї. Державна система соціального захисту має заохочувати й не повинна стримувати прагнення особи покращити умови життя для себе та своєї сім'ї $[27$, п. 6].

\section{Висновки}

На підставі проведеного дослідження можна зробити висновки, що рішення ССПЛ у справі «Левчук проти Украйни» актуалізувало низку таких проблем: захист потерпілих від домашнього насильства; невиконання державою своїх позитивних зобов'язань, які вимагають ужиття певних заходів для забезпечення ефективного користування правами й основоположними свободами, гарантованими Конвенцією; неналежне обгрунтування судових рішень і неврахування національними судами важливих і доречних аргументів сторін, а також застосування застарілих норм законодавства в сучасних умовах як складника здійснення судом юридичної кваліфікації, що призводить до невиконання вимог верховенства права, що стосуються доступу до правосуддя. Кожна з виокремлених проблем є практично значимою, а відтак усі вони є перспективними для подальших наукових розвідок.

\section{Список використаних джерел:}

1. Report on the Rule of Law. Adopted by the Venice Commission at its 86th plenary session (Venice, 25-26 March 2011) on the basis of comments by Mr Pieter van Dijk, Ms Gret Haller, Mr Jeffrey Jowell, Mr Kaarlo Tuori. CDL-AD(2011)003rev. URL: https://rm.coe.int/1680700a61.

2. Кримінальний процесуальний кодекс України : Закон України від 13 квіт. 2012 р. № 4651-VI. URL: https://zakon.rada.gov.ua/laws/ show/4651-17\#Text (дата звернення: 02.02.2021).

3. Про судоустрій і статус суддів : Закон України від 2 черв. 2016 р. № 1402-VIII. URL: https://zakon.rada.gov.ua/laws/show/1402-19\# Text (дата звернення: 02.02.2021).

4. Стратегія гендерної рівності Ради Свропи на 2018-2023 роки. URL: https://rm.coe.int/prems041318-gbr-gender-equality-strategy-2023-ukrnew2/16808b35a4 (дата звернення: 02.02.2021).

5. Чодрі Ш. Доступ жінок до правосуддя : довідник для юристів-практиків. 2018. URL: https://rm.coe.int/methodology-womensaccess-to-justice-ukr-pgg/16809c828d (дата звернення: 02.02.2021).

6. Левчук проти України (Levchuk v. Ukraine) : Рішення ЄСПЛ у справі від 03.09.2020, аява № 17496/19. URL: http://hudoc.echr.coe.int/ rus? $\mathrm{i}=001-207637$ (дата звернення 02.02.2021).

7. Council of Europe Convention on preventing and combating violence against women and domestic violence. URL: https://www.coe.int/fr/ web/conventions/full-list/-/conventions/ $\mathrm{rms} / 090000168008482 \mathrm{e} \quad$ (дата звернення 02.02.2021) 
8. Кривіцька та Кривіцький проти України (Kryvitska and Kryvitskyy v. Ukraine) : Рішення ЄСПЛ у справі від 02.12.2010, заява № 30856/03. URL: https://zakon.rada.gov.ua/laws/show/974_774\# Text (дата звернення: 02.02.2021).

9. Дакус проти України (Dakus v. Ukraine) : Рішення ЄСПЛ у справі від 14.12.2017, заява № 19957/07. URL: http://hudoc.echr.coe.int/ eng?i=001-192194 (дата звернення: 02.02.2021).

10. Садов'як проти України (Sadovyak v. Ukraine) : Рішення ЄСПЛ у справі від 17.05.2018, заява № 17365/14. URL: https://zakon.rada.gov.ua/ laws/show/974 c59\#Text (дата звернення: 02.02.2021)

11. Житловий кодекс Української РCP від 30 червня 1983 р. № 5464-X. URL: https:// zakon.rada.gov.ua/laws/show/5464-10\#Text (дата звернення: 02.02.2021).

12. Цивільний процесуальний кодекс України : Закон України від 18 бер. 2004 р. № 1618-IV. URL: https://zakon.rada.gov.ua/laws/ show/1618-15\#Text (дата звернення: 03.02.2021).

13. Handbook on European law relating to access to justice : European Union Agency for Fundamental Rights and Council of Europe. Luxembourg : Publications Office of the European Union, 2016.

14. Москаль Р. Вимоги верховенства права стосовно доступу до правосуддя. Науковий вісник Начіональної академії внутрішніх справ. 2020. № 115. C. $36-49$

15. Загальна теорія права : підручник / за заг. ред. М.І. Козюбри. Київ : Ваіте, 2016. 392 с.

16. Рішення Рівненського міського суду Рівненської області від 4 квітня 2017 року. Справа № 569/7901/16-щ. URL: http://reyestr.court.gov. ua/Review/65717293 (дата звернення: 02.02.2021).

17. Рішення Колегії суддів судової палати 3 розгляду цивільних справ апеляційного суду Рівненської області від 14 червня 2017 року. URL: https://reyestr.court.gov.ua/Review/67112315 (дата звернення: 02.02.2021).

18. Постанова Верховного Суду у складі колегії суддів Другої судової палати Касаційного цивільного суду від 20 серпня 2018 року. Справа № 569/7901/16-ц. Провадження № 61-27464cв18. URL: https:// reyestr.court.gov.ua/Review/76262124 (дата звернення: 02.02.2021).

19. Васьковский Е.В. Руководство к толкованию и применению законов. Для начинающих юристов. Москва : Конкорд, 1997.
20. Рішення Конституційного Суду України у справі за конституційним поданням 49 народних депутатів України щодо відповідності Конституції України (конституційності) положень частини другої статті 135 Житлового кодексу Української РСР від 20 грудня 2019 року № 12-р/2019. Справа № 1-26/2018(2572/17). URL: https:// zakon.rada.gov.ua/laws/show/v012p710-19\#n2 (дата звернення: 02.02.2021).

21. Пазенок В. Моральний кодекс будівника комунізму. Українська радянська енциклопедія. URL: https://leksika.com.ua/12930501/ure/ moralniy_kodeks_budivnika_komunizmu (дата звернення: 02.02. 2021 )

22. Жилищные права и обязанности советских граждан (по законодательству Союза ССР и Украинской ССР) : Юрид. справ. / В.П. Цемко, П.А. Чеберяк, И.Н. Кучеренко и др. отв. ред. В.П. Цемко. Киев : Наук. думка, 1988.

23. Про іпотеку : Закон України від 5 черв. 2003 p. № 898-IV. URL: https://zakon.rada.gov.ua/ laws/show/898-15\#Text (дата звернення: 03.02.2021).

24. Ухвала Верховного Суду у складі колегії суддів Першої судової палати Касаційного цивільного суду 13 червня 2018 року. Справа № 753/12729/15-ц. Провадження № 61-3959св18. URL: https:// reyestr.court.gov.ua/Review/75042651 (дата звернення: 03.02.2021)

25. Постанова Великої Палати Верховного Суду від 31 жовтня 2018 року. Справа № 753/12729/15-ц Провадження № 14-317цс18. URL: https:// reyestr.court.gov.ua/Review/77696631 (дата звернення: 03.02.2021).

26. Вєренцов проти України (Vyerentsov v. Ukraine) : Рішення ЄСПЛ у справі від 11.04.2013 заява № 20372/11. URL: https://zakon.rada.gov.ua/ laws/show/974 945\#Text (дата звернення: 03.02.2021).

27. Рішення Конституційного Суду України у справі за конституційним поданням у 50 народних депутатів України щодо відповідності Конституції України (конституційності) положень пункту 7 розділу II Закону України «Про запобігання фінансової катастрофи та створення передумов для економічного зростання в Україні» від 7 листопада 2018 року № 9-р/2018. Справа № 1-3/2018(2717/14). URL: https:// zakon.rada.gov.ua/laws/show/v009p710-18\#Text (дата звернення: 03.02.2021)

Tetiana Fulei. Application of the outdated legislation by courts as an obstacle to ensuring access to justice

The article deals with the issue of application of outdated legal provisions by courts, which is an obstacle to ensuring access to justice. Using the ECtHR judgment in Levchuk v. Ukraine, in which a violation of Article 8 of the ECHR has been found due to the State's failure to comply with its positive obligations to effectively protect the applicant from domestic violence, in view of the response of the national courts to the applicant's eviction claim against her former husband, the flawes in the interpretation and application of Article 116 of the Housing Code of the Ukrainian SSR (hereinafter - the Housing Code) in modern conditions have been demonstrated. Based on the analysis of the judgements of national courts in the case of I. Levchuk, it has been concluded that the "omission" of a certain word in text of the law cannot be considered as a proper application. It is emphasized that the "rules of socialist coexistence" in Article 116 of the Civil 
Code is an established legal term of the socialist era, which completely changes its essence in case of removal of the word "socialist", it has been noted that national courts bypass the word "socialist", applying this rule. The problem is outlined: can outdated provisions of housing legislation be considered "applicable law". The problem is outlined: can outdated provisions of housing legislation be considered an "applicable law". The problems of application of Article 109 of the Housing Code, which makes it impossible to evict a person without providing other permanent accommodation, has been demonstrated. The need to interpret Article 109 of the Housing Code in line with its preamble, which declares a solution to the housing problem in Soviet times, has been emphasized. Based on the case-law, the negative consequences for the owner of current mode of application of the article 109 of the Housing Code for the homeowner has been shown. It is emphasized that the perception and application of the ECtHR case law as such, which in principle allegedly does not allow eviction, is erroneous. Given that access to justice envisaged that "the judiciary has power to determine which lawes are applicable and valid in the case, to resolve issues of fact, and to apply the law to the facts, in accordance with an appropriate, that is to say, sufficiently transparent and predictable, interpretative methodology" as one of the requirements of the rule of law according to the Venice Commission's Report on the Rule of Law, it was concluded that the application by the court of improper or invalid law, as well as improper application of the law, is a violation of the rule of law and impedes access to justice.

Key words: access to justice, domestic violence, ECtHR case law, "applicable law", eviction. 